\title{
Can Academic Potential Tests Predict Students' Learning Outcomes?
}

\author{
S. Sundari ${ }^{1, *}$ SW Putro ${ }^{2}$, GA Sadrina ${ }^{3}$ \\ ${ }^{1}$ School of Medicine, Universitas Muhammadiyah Yogyakarta \\ ${ }^{2,3}$ School of Medicine Students, Universitas Muhammadiyah Yogyakarta \\ ${ }^{*}$ Corresponding author. Email: sundari_purbo@yahoo.com.sg
}

\begin{abstract}
The Medical Education Study Program is a favorable department study program at Universitas Muhammadiyah Yogyakarta. Thus, the department increases the students' input standard to keep quality. There are various kinds of tests for selecting new students, including course tests, psychological tests (TPA and MMPI), health tests, and interview tests. Test types used to measure students' cognitive abilities at PSPD are final block exams and tutorial mini-quiz. Both types of tests use Multiple Choice Question (MCQ). The study aims to determine the correlation of academic potential tests with students' cognitive abilities illustrated through mini-quiz scores and block test scores. The research method used was an analytic observational research design using a cross-sectional approach. The sample of the research was 97 students. The analysis results showed that the total TPA results did not affect the mini-quiz and block examinations score $(\mathrm{p}>0.05)$. It can be concluded that there was no relationship between the values of the verbal, numerical, spatial, and overall value of the landfill with mini-quiz values. This study concluded that there was no relationship between the academic potential tests on students' mini-quiz scores in the Medical Education Study Program (PSPD). However, this TPA's results had a positive correlation on numerical sub-tests with the results of their block tests, even though the spatial and verbal sub-tests did not correlate.
\end{abstract}

Keywords: Academic Potential Test, Mini-quiz Value, Numerical, Spatial, Test Score, Verbal Subtest

\section{INTRODUCTION}

The Medical Study Program Faculty of Medicine and Health Sciences (FKIK) Universitas Muhammadiyah is one of the most favorable departments. Thus, the standard becomes higher and aims to keep the quality of department [1]. There are some tests used in the admissions process for new students, namely cognitive test and academic potential test (in Indonesia, it is called by (tes potensi akademik), medical check-up, and interview.

Academic Potential Test is a test used to measure a person's academic ability in general. Therefore, this test can also be used to measure a person's intelligence level [2]. Academic Potential Test aims to determine the predictions of a person's success in college. The test in Indonesia has four types of tests: verbal tests, quantitative tests, reasoning tests, and tests of images or spatial. The Medical Study Program (PSK) has used the Academic Potential Test as one of the new student input standards. Academic Potential Test is expected to be able to predict the success of students in taking their studies.

Students' assessment becomes the most essential part of the learning process. There are eight assessments in the medical study program, one of which is a mini-quiz using multiple-choice questions. This assessment aims to assess students' learning outcomes. Mini-quiz questions are included in the cognitive domain, that is, recalling and reasoning [3]. The tutorial value portion in determining the final block value is $30 \%$, consisting of the average value of $50 \%$ daily activity and the average value of a mini-quiz of $50 \%$ [4]. Many studies have been conducted to determine what tests are associated with learning outcomes, but it is not yet possible to determine which test is the most suitable for selecting new student candidates for medical study programs. This study aims to determine whether the Academic Potential Test is related to the new student miniquiz and block examination scores.

\section{RESEARCH METHODS}

It was a cross-sectional study with 150 students as a population of the study. 97 students of the medical study program then became the sample. There were inclusion and exclusion criteria for this study. Inclusion criteria included students of medical study program batch 2018 who were registered as active students and participated in the whole mini-quiz from block one to block four. Exclusion criteria included students who took part in all mini-quizzes but then they re-blocked or dropped off blocks in class 2018 and students who remediated mini-quiz at the end of the semester. This research was conducted in the Medical Study Program, Faculty of Medicine and Health Sciences, Universitas Muhammadiyah Yogyakarta, starting from 
September 2018 to January 2019. Sampling was carried out after the first-semester of mini-quiz grades (block one to block four) that were available. Analysis of the data used the Pearson correlation test.

\section{RESULT AND DISCUSSION}

Tests were carried out on each sub-test consisting of three sub-tests, verbal tests, numerical tests and spatial tests. Verbal tests consisted of synonym tests, antonym tests, word relationship equivalency tests, word grouping tests and tests to complete missing sentences. The verbal test aimed to determine language effectiveness, understanding, analyzing and interpreting information in a paper. The results showed that the high and low verbal test results were not related to the mini-quiz score as learning outcomes for one semester. The result was the opposite of Sierra, which stated a positive relationship in verbal GRE with success on the national final examination of doctor assistant [5]. Numerical tests contained a series of numbers that reflected how a person could think systematically and structured to solve a problem. Numerical tests consisted of count tests, numerical series tests, letter series tests, numerical logic tests, to numeric tests in stories. The TPA's numerical ability obtained from this study's results did not correlate with the mini-quiz score as a learning outcome. These results were opposite with Brumeister in his research on the statistical correlation of student admissions with the success of students who graduated; one of them obtained verbal and quantitative tests from the GRE with high scores of the final exam that was interconnected [6].

Spatial tests consist of general logic tests, syllogism tests, story logic tests, to diagram logic tests. Spatial tests are intended to find out whether someone can solve a problem with logical reasoning and solving. Based on the study results, the spatial test score had no relation with the miniquiz score. It is contrasted to Muslimin, which found a positive relationship between verbal, quantitative and analytical skills at the TPA with learning achievement [7]. Based on the data analysis, there was no relationship between the total TPA score with the MCQ score. Academic potential test or Graduate Record Examination (GRE) is a test used to measure students' success in undergoing a subject being studied. The material tested on the academic potential test consists of three topics namely verbal, numerical, and spatial. In the verbal test section, there are several sub-test categories such as the antonym test, synonym, verbal analogy of word grouping, and missing word test, while in the numeric test section, there are several sub-test categories such as a series of numbers, series of letters, logic numbers, and numbers in stories. There are several sub-test categories in the spatial tests section, such as analogies, logical reasoning, formal logic, pictures, and analytics [8]. If a student can do a good test of academic potential in terms of a good score obtained, students' success in following the courses will be good too [9]. Academic potential tests are also useful as an illustration of students to achieve success or understand a course that can analyze and solve a problem and predict student success in college [10].
Verbal ability is the ability to measure someone in working on a word problem. It can reflect someone in arranging words and sentences. Based on the results, the verbal ability was not related to the MCQ score, indicating that students in understanding MCQ questions did not require deep reasoning to understand and answer MCQ questions because MCQ questions consisted of many types of questions from short questions to understanding a case or scenario that need a good verbal analysis [11].

Numerical ability is the ability to measure someone in working on a problem of numbers and calculations that contain the ability of algebra and reasoning. In this case, the test taker will be measured for his ability to operate numbers such as addition, subtraction, multiplication, and division of numbers [12]. This ability reflects a person in thinking logically. There are some scores used in this study, namely, academic potential test, mini-quiz, and block test. Here are the scores.

Table 1. Academic potential test score, mini-quiz, and block test.

\begin{tabular}{|c|c|c|c|c|}
\hline & $\mathbf{N}$ & Min & Max & Mean \pm Std. Deviation \\
\hline Verbal score & 97 & 13 & 24 & $18.73 \pm 2.343$ \\
\hline Numeric score & 97 & 8 & 29 & $19.70 \pm 3.626$ \\
\hline Spatial score & 97 & 23 & 36 & $29.24 \pm 3.233$ \\
\hline Total score & 97 & 56 & 79 & $67.69 \pm 6.039$ \\
\hline Mini-quiz score & 97 & 46.2 & 82.9 & $67.83 \pm 7.257$ \\
\hline Block test score & 97 & 35.6 & 75.1 & $53.78 \pm 8.373$ \\
\hline
\end{tabular}

Based on table 1, it can be seen that the average score from each academic potential test category (verbal, numeric, and spatial) was $18.73,19.70$ and 29.24. The average score of a mini-quiz in a semester, consisting of four blocks, was 67.8312 , then the average score of the block test was 53,78 . Based on the normality test, the data can be considered as normally distributed.

Table 2. Correlation test between the verbal, numeric, spatial score, the total TPA, and a miniquiz score

\begin{tabular}{|c|c|c|c|}
\hline No & Variable & R & Sig. \\
\hline \multirow{2}{*}{1} & Verbal score & \multirow{2}{*}{-0.058} & 0.573 \\
\cline { 2 - 2 } & Mini-quiz score & \multirow{2}{*}{0.057} & 0.578 \\
\hline \multirow{2}{*}{2} & Numeric score & & \\
\cline { 2 - 2 } & Mini-quiz & -0.136 & 0.184 \\
\hline \multirow{2}{*}{4} & Spatial score & \multirow{2}{*}{-0.061} & 0.555 \\
\cline { 2 - 3 } & Mini-quiz & \\
\cline { 2 - 3 } & Total score of TPA & & \\
\hline
\end{tabular}

It can be concluded that there was no relation between mini-quiz score and verbal, numeric, and total score of TPA $(\mathrm{p}>0,05)$. 
Table 3. Table of Correlation between verbal, numeric, spatial, total score of TPA and MCQ

\begin{tabular}{|c|c|c|}
\hline $\begin{array}{c}\text { Relation between } \\
\text { variables }\end{array}$ & R & Sig \\
\hline $\begin{array}{c}\text { Verbal score } \\
\text { MCQ score }\end{array}$ & 0.000 & 0.998 \\
\hline $\begin{array}{c}\text { Numeric score } \\
\text { MCQ score }\end{array}$ & 0.276 & 0.006 \\
\hline $\begin{array}{c}\text { Spatial score } \\
\text { MCQ score }\end{array}$ & -0.202 & 0.046 \\
\hline $\begin{array}{c}\text { TPA total score } \\
\text { MCQ score }\end{array}$ & 0.063 & 0.538 \\
\hline
\end{tabular}

In solving the problem scientifically and doing mathematical calculations, the person manages logic and numbers to compile his daily thoughts. This theory is closely related and in line with what is described in this study's results, where numerical ability had a positive relationship with the value of MCQ [13].

Spatial ability is the ability to measure someone in working on a reasoning problem of how an image is reflected with the right results in the answer, grouping images according to categories, and identifying [14]. This ability reflects a person in doing and recognizing sketches of images of objects processed in his mind that prioritizes the management of three-dimensional space, shapes, images, and colors. This person's nature will prioritize or rely on mental imagination and the scope of graphics in their daily lives. This theory is contrary to the results of this study where spatial ability had a negative relationship with MCQ's value; in the final exam block, students did not prioritize the process of reasoning in the form of space imagination or logic in completing the questions given in the final exam block [15].

This study is in line with previous research entitled "The Relationship of Mathematics Ability and Academic Potential Tests for Mathematics Education Teachers "Training program IKIP PGRI Pontianak" which concluded that there was no significant correlation between mathematical ability and TPA of Mathematics Education Teachers' Training program IKIP PGRI Pontianak. It was caused by students' mindsets who thought that mathematics was just formula and number. They should think that mathematic requires logical thinking as well as the function of academic potential tests that require high concentration, calmness in answer, and practice on the tricks of the process in a short time [16].

In this study, each element of the variable or the whole variable did not have a significant correlation. It may be caused by several factors in the learning process: lecturers' ability to deliver material, student learning preparation, different learning methods for each student, and environmental conditions [17]. In addition, other studies mentioning the influencing factors can also be divided based on internal and external factors. Internal factors include physical conditions (physical and nutritional conditions), psychology (cognitive abilities, maturity, preparedness, attention, talent, interest, and motivation), and five senses (hearing and sight), while external factors include the environment (social and natural) and instrumental (various learning support tools, teaching materials, tools, methods, sources) [18]. The same research stated that other factors such as family factors (level of parental education, parental income or economy, relationships between family members, provision of learning facilities, and the number of dependent parents), age, gender, community factors, and factors school or campus also influence a child's learning achievement [19].

This research is also supported by the same opinion about the prediction of learning achievement, which showed that the Undergraduate Grade Point Average (UGPA) score and the Graduate Record Examination (GRE) academic aptitude test were good predictors of success in achieving learning outcomes, but UGPA was considered to be a better predictor than GRE. Previous research stated that the grade point average (GPA) was the key to the correct predictor and significantly correlated the extent of student academic performance [20]. Other research also showed that there was a predictor to measure a student's learning achievement using the Scholastic Aptitude Test (SAT). This research was conducted on students of first-degree accounting studies at Purdue University, stating that the SAT had a huge role in influencing the students' learning achievement compared to GPA, motivation and effort, and academic experience [21]. This research is also supported by research conducted at the Faculty of Medicine's first-year students, the University of Lampung, in 2014. This research revealed that the relationship of Self-Directed Learning Readiness (SDLR), in which students were required to study independently by the final exam block results, had a positive correlation. However, the strength of the correlation was still weak, so that we could not rule out other factors that affected learning achievement [22].

Considering that the research was taken from the firstgrade students of the medical study program batch 2018, the curriculum might affect this result. The first-year university students are in adaptation time to the curriculum system. Most of the high school curriculum is Teacher Centered Learning (TCL), while universities used student-centered learning and problem-based learning (PBL). It is in line with the study conducted on the Faculty of Medicine, Jambi University and Gadjah Mada University students, revealing that at the beginning of PBL implementation, the students felt anxiety, depression, and learning difficulties. Apart from the student's intrinsic factor, at the beginning of the lecture, the faculty as a provider of facilities and infrastructure should also participate in equipping students to manage academic schedules, lecturers' roles, the interaction between students, and various examinations and the independent learning system itself [23].

This study also agreed with the research conducted by the committee of doctoral students admission of biomedical science study programs at Vanderbilt University, Tennessee, United States, stating that the GRE was not proven in predicting who would survive and get a Ph.D., pass in various examinations during the study period, have a shorter time to survive, get involved in many international and national conference presentations, and write and 
publish various papers in several international journals. Thus, the committee for admission of undergraduate students in biomedical science must reconsider not emphasizing the GRE score as the main predictor of prospective Ph.D. students during their education [24].

The factors can be an essential reference between academic potential test scores (including aspects of verbal, numerical, and spatial) with the final MCQ test results, where internal and external factors cannot be separated from each other that affect the level of correlation between variables. Broadly speaking, in this study, the academic potential test cannot be a definite benchmark or predictor in predicting students to process and get maximum learning results according to their academic potential test scores.

\section{CONCLUSION}

It can be concluded that there was no relationship between academic potential test, mini-quiz score, and also block test for medical study program students at Universitas Muhammadiyah Yogyakarta. This result can be used to provide recommendations for medical study program staff. The recommendations can include how students handle the course, evaluate the test constructed by the team, and provide a comfortable learning environment for students.

\section{ACKNOWLEDGMENT}

The authors thank Universitas Muhamadiyah Yogyakarta for supporting this research.

\section{REFERENCES}

[1] Santosa, A. B. (2013). Seleksi Calon Mahasiswa Baru Terhadap Kualitas Lulusan. Cakrawala Pendidikan, 52.

[2] Hariwijaya, T. P. (2006). Tes Potensi Akademik Persiapan Masuk Perguruan Tinggi dan Masuk Kerja. Yogyakarta: CV. Andi Offset.

[3] Utami, S. N. (2016). Peran Prior Knowledge terhadap Kemampuan Kognitif Mahasiswa. JK Unila.

[4] Panduan Akademik Program Studi Pendidikan Dokter. (2016). Yogyakarta.

[5] Sierra Moore et al. (2019). Factors Associated with Academic Performance in Physician Assistant Graduate Programs and National Certification Examination Scores. A Literature Review. Health Professions Education.

[6] Jay Burmeister et al. (2014). Correlation of Admissions Statistics to Graduate Student Success in Medical Physics. Journal of Applied Clinical Medical Physics.

[7] Muslimin, Z. I. (2012). Prestasi Belajar Mahasiswa Ditinjau dari Jalur Penerimaan Mahasiswa Baru, Asal Sekolah, dan Skor Tes Potensi Akademik. Jurnal Penelitian Psikologi.

[8] Riswanto, Indra. (2013). Pengembangan Soal Tes Potensi Akademik Numerik Penerimaan Siswa Baru Smp Berbantuan Media Berbasis Wireless Application Protocol Java 2 Micro Edition (J2me). Jember: Jurnal
Pendidikan dan Pembelajaran (PANCARAN) FKIP Universitas Jember. Vol. 02. No. 01, 95-104.

[9] Azwar, Saifuddin (2008). Kualitas Tes Potensi Akademik versi 07A. Jurnal Penelitian dan Evaluasi Pendidikan. No. 2 tahun XII.

[10] Widhiarso, W. (2016). Sekilas Tentang Potensi Akademik. Retrieved June 7, 2018, from http://upap.psikologi.ugm.ac.id/sekilas-tentang-tespotensi-akademik/

[11] Susilo. (2013). Tes Potensi Akademik. Yogyakarta: Pustaka Solomo.

[12] Slameto. (2007). Evaluasi Pendidikan. Jakarta: Bumi Aksara

[13] Gardner, H. (1999). The disciplined mind: What all students should understand. NewYork, NY: Simon \& Schuster.

[14] Aristo, Candra (2012). Rahasia 10 Detik/Soal Menyelesaikan Soal TPA Pascasarjana dan Beasiswa (S2/S3) (edisi ke-2). Wahyu Media. hlm. 268. ISBN 979795-576-1. Diakses tahun 2012

[15] Jayantika, I G A N Trisna., Ardana, I Made., \& Sudiarta, I Gusti Putu. (2013). Kontribusi Bakat Numerik, Kecerdasan Spasial, dan Kecerdasan Logis Matematis terhadap Prestasi Belajar Matematika Siswa SD Negeri di Kabupaten Buleleng. e-Journal Program Pascasarjana Universitas Pendidikan Ganesha, (Online), Vol. 2.

[16] Ardiawan, Yadi. (2015). "Analisis Kesalahan Mahasiswa dalam Menyelesaikan Soal Induksi Matematika di IKIP PGRI Pontianak". Jurnal Pendidikan Informatika dan Sains 4(1): 147-163.

[17] Ruseffendi. (2005). Dasar-dasar Penelitian Pendidikan \& Bidang Non-Eksakta Lainnya. Bandung: Tarsito.

[18] Djamarah, Syaiful Bahri. (2008). Psikologi belajar. Jakarta: Rineka Cipta.

[19] Slameto. (2003). Belajar dan Faktor-faktor yang Mempengaruhinya. Jakarta: Rineka Cipta.

[20] Newton, Sarah.E., Moore, Gary. (2007). Undergraduate Point Average and Graduate Record Examination Scores: The Experience of One Graduate Nursing Program. Ovid, XXVIII(6): 327-331.

[21] Robert K. Eskew and Robert H. Faley. (1988). Some Determinant of Student Performance in the First CollegeLevel Financial Accounting. Issued in Accounting Education Volume 15.

[22] Saputra, Oktadoni., Lisiswanti, Rika., Aftria, Marizka Putri. (2015). Korelasi Self-Directed Learning Readiness (SDLR) terhadap Prestasi Belajar Mahasiswa Tahun Pertama Fakultas Kedokteran Universitas Lampung Tahun Ajaran 2014/2015. Prosiding Seminar Presentasi Artikel Ilmiah Dies Natalis FK Unila ke-13. Lampung: FK Unila 
[23] Aryanty, Nindya., Rahayu, Gandes Retno., Suryadi, Efrayim. (2013). Pengalaman Belajar Mahasiswa Terkait Peran Skenario Dalam Tutorial. Jurnal Pendidikan Kedokteran Indonesia, II(1): 62-70.

[24] Koehler, Liane Moneta., Brown, Abigail.M., Petrie, Kimberly.A., Evans, Brent.J., Chalkley, Roger. (2017). The Limitations of the GRE in Predicting Success in Biomedical Graduate School. PLOS Medicine. XII(1): 1-17. 